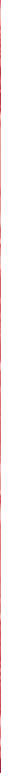

Routledge Studies in Marketing

\title{
MARKETING, RHETORIC, AND CONTROL
}

\section{THE MAGICAL FOUNDATIONS OF MARKETING THEORY}

Chris Miles

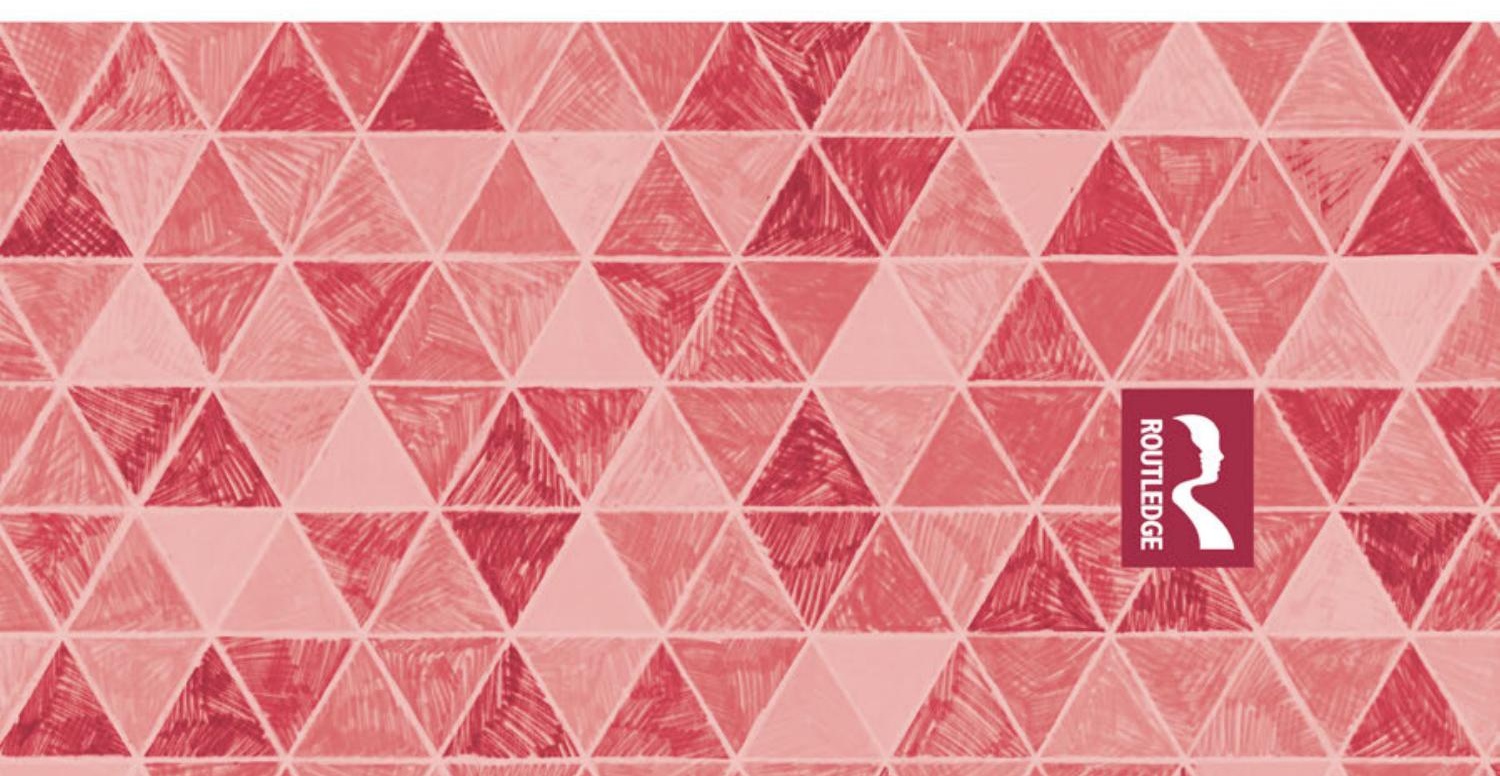




\section{Marketing, Rhetoric, and Control}

Marketing, Rhetoric, and Control investigates the tensions that surround the place of persuasion (and, more broadly, control) in marketing. Persuasion has variously been seen as an embarrassment to the discipline, a target for anti-marketing sentiment, the source of marketing's value in the modern organisation, a mysterious black box inside the otherwise rational and logical endeavour of enterprise, and a rather insignificant part of the marketing programme. This book argues that this multifarious reputation for persuasion within marketing stems from the influence of two quite oppositional paradigms-the scientific and the magico-rhetorical-that ebb and flow across the discourses of its discipline and practice.

Constructing an interface between original, challenging close readings of texts from the beginnings of the Western rhetorical tradition and an examination of the ways in which marketing has set about describing itself, this text argues for a Sophistic interpretation of marketing. From this perspective, marketing is understood as providing intermediary services to facilitate the continuing exchange of attention and regard between firm/client and stakeholders. It seeks to manage and direct this exchange through an appreciation of the changing rational and irrational motivations of the firm and stakeholders, using these as resources for the construction of both planned and improvised persuasive interactions in agonistic (or competitive) environments.

This book is aimed primarily at researchers and academics working in the fields of marketing, marketing communications, and the related disciplines of marketing theory, critical marketing, and digital marketing. It will also be of value to marketing academics in business schools, including those working in the areas of media and communication studies who have an interest in commercial and corporate communication, brand use of interactive media, and communication theory.

Chris Miles is a Senior Lecturer in Marketing and Communication at Bournemouth University, UK. 


\section{Routledge Studies in Marketing}

This series welcomes proposals for original research projects that are either single or multi-authored or an edited collection from both established and emerging scholars working on any aspect of marketing theory and practice and provides an outlet for studies dealing with elements of marketing theory, thought, pedagogy and practice.

It aims to reflect the evolving role of marketing and bring together the most innovative work across all aspects of the marketing 'mix'-from product development, consumer behaviour, marketing analysis, branding, and customer relationships, to sustainability, ethics and the new opportunities and challenges presented by digital and online marketing.

Available titles in this series:

Marketing, Rhetoric, and Control

The Magical Foundations of Marketing Theory

Chris Miles 


\section{Marketing, Rhetoric, and Control \\ The Magical Foundations of Marketing Theory}

\section{Chris Miles}


First published 2018

by Routledge

711 Third Avenue, New York, NY 10017

and by Routledge

2 Park Square, Milton Park, Abingdon, Oxon, OX14 4RN

Routledge is an imprint of the Taylor \& Francis Group, an informa business

(C) 2018 Taylor \& Francis

The right of Chris Miles to be identified as author of this work has been asserted by him in accordance with sections 77 and 78 of the Copyright, Designs and Patents Act 1988.

All rights reserved. No part of this book may be reprinted or reproduced or utilised in any form or by any electronic, mechanical, or other means, now known or hereafter invented, including photocopying and recording, or in any information storage or retrieval system, without permission in writing from the publishers.

Trademark notice: Product or corporate names may be trademarks or registered trademarks, and are used only for identification and explanation without intent to infringe.

Library of Congress Cataloging-in-Publication Data

A catalog record for this book has been requested

ISBN: 978-1-138-66727-3 (hbk)

ISBN: 978-1-315-61898-2 (ebk)

Typeset in Sabon

by Apex CoVantage, LLC 
For Şebnem 


\section{Contents}

Acknowledgements

viii

Introduction

1 A History of Rhetoric for Marketers 9

2 Marketing Scholarship and Rhetoric $\quad 48$

3 Control and the Discourse of Marketing Science 73

4 A Rhetorical Approach to Marketing as Exchange 98

5 Marketing and Sophism-A Comparison 115

6 Magic, Sympathy, and Language 130

7 The Magical Roots of Rhetoric 142

8 Magical Persuasion and Marketing 155

9 A Sophistic Marketing 190

$\begin{array}{ll}\text { Index } & 211\end{array}$ 


\section{Acknowledgements}

I would like to thank a number of people who have made the conception and writing of this book an easier process. Both Nicholas O'Shaughnessy and Yasmin Ibrahim encouraged my research on rhetoric and marketing from an early stage and acted as sympathetic, influential sounding boards at the start of this project. I am very grateful for the sterling support that I have received in my work from Janice Denegri-Knott in her capacity as Head of Research for the Department of Corporate and Marketing Communication at Bournemouth University and also as the Head of the Promotional Cultures and Communication Centre there. Other colleagues at Bournemouth University, particularly Rutherford and David Alder, have also been very generous in listening to my ramblings and offering sage advice (most of which I have flatly ignored in the interest of consistent cantankerousness). Tomas Nilsson has been an enthusing conversational partner for much of the writing of this book and his commitment to the rhetorical nature of marketing and management work is energizing. Finally, I would like to thank my wife, Şebnem, to whom this book is dedicated, for always supporting me, inspiring me, keeping me sane, and helping me to remember the magic power of language every day. 


\section{Introduction}

In this study, I investigate the tensions that surround the place of persuasion (and, more broadly, control) in marketing. Persuasion has variously been seen as an embarrassment to the discipline, a target for anti-marketing sentiment, the source of marketing's value in the modern organisation, a mysterious black box inside the otherwise rational and logical endeavour of enterprise, and a rather insignificant part of the marketing programme. I will argue that this multifarious reputation for persuasion within marketing stems from the influence of two quite oppositional paradigms-the scientific and the magico-rhetorical-that ebb and flow across the discourses of its discipline and practice.

The scientific endeavour can be characterised as an effort to strip human investigation, and subsequent practice, of any confounding subjective influence, to objectively lay bare the workings of the natural world without becoming ensnared in the illusions of ideology, religion, myth, and received wisdom. Fundamental to all of these harbingers of error is that they are embedded in language. The careless use of language has been seen as the enemy of the objective discovery of truth since the birth of the modern scientific method (Stark, 2009). The early experimentalists of the Royal Society, for example, sought to eradicate figurative language and cultivate a plainness of style that focused not upon "The Artiface of Words, but a bare knowledge of things" (Sprat, cited in Longaker, 2015, p. 16). This attitude has also suffused much of the intellectual history of economics, commerce and management, where the patina of objective, 'scientific' discourse is important in persuading actors of the unbiased, incontrovertible logic of theories, policies and decisions (McCloskey, 1985; Miller, 1990; Greatbatch and Clark, 2005). Yet, as my own language here implies, the valorising of a plain and factual style, shorn of rhetorical figuration and emotional appeals, is itself a clear rhetorical strategy. Persuasive language does not have to appear florid and overflowing with figuration-it can instead adopt an empirical tone, relying upon the rhetoric of tables and matrices, to seduce readers into believing that the 'logic of science' is operating across its discourse. When academic and practitioner voices speak of banishing persuasion and rhetoric, then, they are often simply taking the opportunity to implement a 


\section{Introduction}

particular rhetorical strategy of their own, a strategy which at many level is concerned with the manufacturing and maintenance of control.

In order to examine the place of persuasion within marketing theory, one inevitably will have to explore the relationship that the discipline has with scientific discourse (and scientific methodology as a discourse strategy). Yet, as I have already indicated, there is another discourse paradigm that has just as much influence over the development and self-construction of the marketing discipline-the magical worldview. Here, language is something that can enchant, cast a glamour, control from afar, and influence without recourse to logic or facts. Knowing the right set of words (the appropriate incantation) can give you power over others and reduce the confusion of everyday life. Such a power is naturally attractive to us all-but marketing practitioners, who deal constantly with the effort to find the right combination of words to invoke their brand's benefit as effectively as possible are perhaps closer than any other contemporary profession to the allure of the magical paradigm of language. Marketing theorists, who seek to formalise and explain the practice to themselves, their students, and (hopefully) professionals, are inevitably exposed to the assumptions of magical influence that I will show are common across the discipline. They might react to these assumptions, try to exorcise them, construct their theories in order to leave no room for them-but they inevitably become open to infection by them just as they are at the mercy of the assumptions of scientific discourse.

I intend to show that at the root of both the scientific and magical paradigms of language is the same basic concern-control. Marketing is obsessed with control-it is its very lifeblood. Accordingly, it should come as no surprise that marketing theory and practice constantly flip-flop between scientific and magical approaches to language. However, the relationship between the two is not a simple binary one, and it is the tradition of rhetoric which gives important clues as to how they bind together. The study and practice of rhetoric (the classical art of persuasion) has similarly been entwined within variegated constructions of rationality and irrationality throughout its theory and practice. I will demonstrate that marketing is an institutionalised contemporary manifestation of the rhetorical enterprise, particularly as the Sophists conceived of it, and as such can greatly profit from a careful consideration of the history of its mother discipline and the way in which society has at turns embraced and demonised it. This is particularly important at this stage of marketing's evolution. Concerns regarding marketing's authenticity, transparency, manipulative intentions, and effectiveness are rife both within and without the discipline. Marketing academics, with varying degrees of alarmist language, worry about the future of both the academic discipline and the profession (Thomas, 2006; Merlo, 2011; Varey, 2013; Clark et al., 2013; Verhoef and Leeflang, 2009) while report after report demonstrates the crisis of trust that brands face online due to annoying and intrusive control-oriented marketing practices (Daly, 2016). Theories (or proto-theories) such as the Service-Dominant logic (Vargo and Lusch, 2004) 
can be seen as attempts to re-define marketing in the face of such threats, yet they do this at the cost of making marketing less and less relevant. What is needed, instead, is an honest approach to the centrality of control to the marketing enterprise, one which can bring nuance and insight to the consideration of control rather than simply trying to act as if it is not (or should not be) there. This is what this study attempts to do by making a case for understanding marketing as a Sophistic enterprise, one which is focused upon the control (or management) of attention (or what I will call regard) through a persuasive, interactive engagement with stakeholders in an agonistic (i.e. competitive) environment. In order to argue this case, the reader must be taken through a number of stages and exposed to some quite diverse areas of scholarship and practice. I will now outline the course of the argument that I will be developing over the next nine chapters.

\section{Synopsis}

The first part of the book establishes the extent to which rhetoric has already figured as an object of marketing scholarship. In order to do this, and to prepare the reader of the development of my argument in later chapters, I start with an overview of the history of Western rhetoric. What writing there has been to date on the place of rhetoric within marketing practice and theory has tended to have to skimp heavily when supplying the historical and developmental context to rhetoric. This acts as a disadvantage for the further acceptance of rhetorical perspectives in the discipline because it leaves most readers with only a cursory understanding of what rhetoric really is and how much depth there exists in the scholarship that has grown up around it for more than two thousand years. If all we know of rhetoric is that Aristotle said that there were three different types of persuasive argument (ethos, logos, and pathos) and that it also has something (though we might not be sure what) to do with metaphors and figures of speech, then it is not surprising that we might not appreciate how much insight rhetoric can give us into the whole gamut of marketing thought. While there are many worthy primers of rhetoric available to the interested reader (Conley, 1990; Murphy et al., 2014; Kennedy, 1994; Smith, 2003; to name but a few), there are none that seek to summarise the story of the discipline for a marketing audience. Consequently, I will endeavour to lay out the important aspects of the study and practice of rhetoric as they will relate to my later, more involved, arguments regarding control, scientism, and magical thinking. Those readers who are already familiar with the rhetorical tradition are urged to jump straight to Chapter 2. It is here that I review the different ways in which marketing scholars have already engaged with aspects of rhetoric. For in linking rhetoric and marketing I am thankfully not starting ab initio. Even before Tonks' (2002) clarion call for rhetoric to have a "central location in making sense of marketing management" (p. 806) there had been a growing weight of research investigating the part that traditional 


\section{Introduction}

rhetorical approaches to persuasion could have in explaining the power of textual and visual tactics in advertising and public relations (Bush and Boller, 1991; McQuarrie and Mick, 1992, 1996, 1999; Scott, 1994; Stern, 1988, 1990; Tom and Eves, 1999). This tradition has continued and broadened in recent years, with scholars such as Brown (2002, 2004, 2005, 2010), Hackley $(2001,2003)$ and myself (Miles, 2013, 2014a, 2014b) using rhetorical framings to discuss the ways in which marketing speaks about itself and how academics and practitioners use discourse to construct various aspects of what it means to be doing marketing. Chapter 2, therefore, brings us 'up to date' with the small but significant 'rhetorical turn' in marketing.

If, so far, marketing scholarship has not been overly receptive to arguments that it should be interpreted as an instantiation of rhetoric it is worth investigating just how it is that marketing does actually see itself. Chapter 3, therefore, begins by examining the foundation myths of marketing, looking at where scholars think the discipline comes from and how it has been thought to have developed in its formative years. Central to this examination is a consideration of the way that marketing has sought to define itself as a science and the sometimes quite vociferous debates that have flared up around this issue, particularly between those promoting a 'relativistic' interpretation of marketing truth and those supporting a far more empirical, 'realist' one. These debates are important for the stage that they set for my later analysis of the Sophistic character of the marketing enterprise, but they can also be analysed as attempts to run away from considering marketing's true nature as a discipline of rhetorical control. This leads me directly to a discussion of the centrality of control in any consideration of marketing practice and theory. I start this discussion by tracing an alternative history of marketing in what Beniger (1986) has called the "crisis of control" (p. 219) accompanying the Industrial Revolution. I will argue that modern marketing developed as a technology of control designed to stimulate and direct consumer demand and that these origins have continued to direct its evolution, despite the manifold extensions and re-focussings that the practice and discipline have undergone in the following decades. Marketing's ability to control consumption is dependent also upon the intermediary position of the marketing practitioner. The description of marketers as 'middlemen', though common in the late nineteenth and early twentieth century has largely fallen by the wayside. However, I will argue that the phrase holds an important key to the way in which the modern profession can be seen as reflecting a truly ancient dynamic. This is a cue for our first return to Plato and his dealings with early marketers (or retailers and traders) in order to worry away at the origins of this middle position of the marketer. Marketing historians have often reached for Plato when they have wished to underscore the esteemed history of the discipline, and I will consider the rhetorical ramifications for such an appeal. This will also serve as context for my oppositional reading of Plato's description of marketing middle men which occurs in Chapter 4. Chapter 3 finishes with a consideration of marketing 
scholarship's unquenchable desire to increase its scope as far as possible and relates this to the issue of exchange, a concept which has been repeatedly put forward as the one motif which can unify all marketing thought.

Chapter 4 builds upon the discussion of exchange that finishes the previous chapter and uses it to present an initial conception of how marketing can be considered an instantiation of the rhetorical discipline. I begin by exploring the ramifications of understanding marketing as an attempt to control the flow of value. I adopt the idea of the marketer as an intermediary but also return to Plato's discussion of the origins of the marketer in order to provide a detailed, Sophistic, oppositional reading of how the urmarketer functions in society. This allows me to offer an initial definition of marketing as rhetoric, a definition which is then qualified, expanded upon, and altered over the course of the chapter and its examination of the ways in which Plato deals with the infecting, liminal, dangerous presence of marketing in his ideal city-states. The chapter culminates with an argument, following Lanham (2006), for basing an understanding of marketing as rhetoric upon the provision of services to facilitate the exchange of attention.

Having argued for the broadly rhetorical nature of marketing, in Chapter 5 I make the case for considering marketing as particularly Sophistic. Once again, I return to Plato and the issue of the middle position of the marketer and demonstrate how that philosopher treated the Sophists in a very similar way-as infecting, dangerous outsiders who threatened the balance of society and the morals of those who composed it. On this basis I examine the legacy of Sophism, asking what made it unique as a rhetorical approach and what made it so threatening to Plato and Aristotle. This leads to a discussion of the way in which marketers are seen in modern society, and how the sorts of accusations and negative sentiment that are routinely thrown at marketing are similar to the ways in which Plato and his philosophical descendants saw both the marketers of their time and the Sophists. I argue that the reason for this similarity comes down to the fact that marketers (both ancient and modern) and Sophists were both performing very similar roles in society based upon controlling attention and the appreciation of value. Finally, I consider the question of why, if the links between rhetoric and marketing are so clear, has there been so little effort made by scholars of rhetoric to engage with marketing?

Much of Chapters 4 and 5 is concerned with the consequences of millennia of public and scholarly unease with marketing and rhetoric, with attempts to control others for commercial, political, or personal gain. A lot of this unease comes from the ways in which rhetoric and marketing remind people of magic. Magic is also about controlling people and things, destiny and luck. And it has a significant part to play in the practice of early rhetoric, particularly Sophistic rhetoric. There are, also, very close connections between marketing and magic, both in terms of the ways that consumers think of products and consumption and the ways that scholars outside marketing have occasionally attempted to explain its power and purpose. The next three chapters of the book deal with how magic, rhetoric, and 


\section{Introduction}

marketing come together. Firstly, Chapter 6 reviews the Western scholarly engagement with magic, the way that it has been defined around attempts at control, and the importance of language in our understandings of what it is. This then allows us to move on in Chapter 7 to a detailed consideration of how the Sophistic approach to language was one based upon a consideration of the magical power of speech. This chapter argues that the deep roots of early rhetoric in ritual and magical performative language constituted a significant part of the threat seen by Plato and Aristotle in the Sophists' teachings and public demonstrations. Consequently, much of the systematisation of rhetoric, its bureaucratisation, can be seen as a series of attempts to expunge magic (as conveyed in ritual patternings, highly figurative language, vivid imagery) from public disputation. Although the 'magical' aspect of rhetoric never truly disappeared, authorities concerned with managing political, legal, and ceremonial disputation and declamation have often tended to take serious measures to keep it on the outside of the establishment. I argue that the practice of marketing can be seen as the last refuge of the magical roots of magic, and it marks, ironically, a (qualified) triumph after many millennia of marginalisation of this tradition. Chapter 8 then considers a number of instances in non-marketing and marketing scholarship where marketing or consumption have been identified with magic or sorcery. Examining the work of Williams (1980), Williamson (2002) and Jhally (1989), amongst a number of others, I argue that scholars working outside the marketing academy have often used the accusation of magical practice against marketing as a way of damning it, or publicly shaming it and the capitalist system that they argue utilises it to spread a glamour in front of the reality of the production and consumption process. As a counter to this, I also examine the consumer culture theory literature that seeks to uncover the magical thinking behind consumption experiences. I argue that as insightful as it is, this strand of marketing scholarship turns away from any real engagement with the magical nature of marketing itself, rhetorically positioning the consumer as the only agent in the creation of consumption magic. While it, therefore, recognises the continuing importance of magic in the modern market, it tells only half of the story. Instead, if we examine the relationship between magic, rhetoric, and marketing, we can fully appreciate the position of the marketer as both magician and rhetor.

The final chapter of the book, Chapter 9, returns to the establishment of a Sophistic understanding of marketing, and works towards presenting an improved version of the definition of marketing originally presented in Chapter 4. The chapter revisits and deepens major themes from the previous chapters in order to arrive at a more rounded conception of marketing as rhetoric. It considers the value of relativism, improvisation, magical thinking, and an agonistic perspective in understanding what makes marketing powerful, desirable, and unique. It also argues that, without a recognition of the centrality of control to what marketing does, a full understanding of marketing's place in society will be always out of reach. 


\section{References}

Beniger, J. (1986). The Control Revolution: Technological and Economic Origins of the Information Society. London: Harvard University Press.

Brown, S. (2002). The Spectre of Kotlerism: A Literary Appreciation. European Management Journal, 20(2), 129-146.

Brown, S. (2004). Writing Marketing: The Clause that Refreshes. Journal of Marketing Management, 20(3-4), 321-342.

Brown, S. (2005). Writing Marketing: Literary Lessons From Academic Authorities. London: Sage.

Brown, S. (2010). Where the Wild Brands Are: Some Thoughts on Anthropomorphic Marketing. The Marketing Review, 10(3), 209-224.

Bush, A., and Boller, G. (1991). Rethinking the Role of Television Advertising During Health Crises: A Rhetorical Analysis of the Federal AIDS Campaigns. Journal of Advertising, 20(1), 28-37.

Clark, T., Key, T. M., Hodis, M., and Rajaratnam, D. (2013). The Intellectual Ecology of Mainstream Marketing Research: An Inquiry Into the Place of Marketing in the Family of Business Disciplines. Journal of the Academy of Marketing Science, 42(3), 223-241.

Conley, T. (1990). Rhetoric in the European Tradition. White Plains, NY: Longman.

Daly, C. (2016). Keep Social Honest Research: Why Transparency Is Key for Brands to Help Build Trust With Consumers on Social Media. Chartered Institute of Marketing Website. https://exchange.cim.co.uk/editorial/keep- social-honest-research/ [Accessed June 24, 2016].

Greatbatch, D., and Clark, T. (2005). Management Speak: Why We Listen to What Management Gurus Tell Us. New York: Routledge.

Hackley, C. (2001). Marketing and Social Construction: Exploring the Rhetorics of Managed Consumption. London: Routledge.

Hackley, C. (2003). 'We Are All Customers Now . . .' Rhetorical Strategy and Ideological Control in Marketing Management Texts. Journal of Management Studies, 40(5), $1325-1352$.

Jhally, S. (1989). Advertising as Religion: The Dialectic of Technology and Magic. In L. Angus and S. Jhally (Eds.), Cultural Politics in Contemporary America. New York: Routledge, 217-229.

Kennedy, G. (1994). A New History of Classical Rhetoric. Princeton, NJ: Princeton University Press.

Lanham, R. (2006). The Economics of Attention: Style and Substance in the Age of Information. Chicago: University of Chicago Press.

Longaker, M. (2015). Rhetorical Style and Bourgeois Virtue. University Park, PA: The Pennsylvania State University Press.

McCloskey, D. (1985). The Rhetoric of Economics. Madison: University of Wisconsin Press.

McQuarrie, E. F., and Mick, D. G. (1992). On Resonance: A Critical Pluralistic Inquiry Into Advertising Rhetoric. Journal of Consumer Research, 19(2), 180-197.

McQuarrie, E. F., and Mick, D. G. (1996). Figures of Rhetoric in Advertising Language. Journal of Consumer Research, 22(4), 424-438.

McQuarrie, E. F., and Mick, D. G. (1999). Visual Rhetoric in Advertising: Textinterpretive, Experimental, and Reader-response Analyses. Journal of Consumer Research, 26(1), 37-54. 


\section{Introduction}

Merlo, O. (2011). The Influence of Marketing From a Power Perspective. European Journal of Marketing, 45(7/8), 1152-1171.

Miles, C. (2013). Persuasion, Marketing Communication, and the Metaphor of Magic. European Journal of Marketing, 47(11/12), 2002-2019.

Miles, C. (2014a). Rhetoric and the Foundation of the Service-Dominant Logic. Journal of Organizational Change Management, 27(5), 744-755.

Miles, C. (2014b). The Rhetoric of Managed Contagion: Metaphor and Agency in the Discourse of Viral Marketing. Marketing Theory, 14(1), 3-18.

Miller, C. (1990). The Rhetoric of Decision Science, or Herbert A. Simon Says. In Herbert W. Simons (Ed.), The Rhetorical Turn. Chicago: The University of Chicago Press, 162-184.

Murphy, J., Katula, R., and Hoppmann, M. (2014). A Synoptic History of Classical Rhetoric. London: Routledge.

Scott, L. M. (1994). Images in Advertising: The Need for a Theory of Visual Rhetoric. Journal of Consumer Research, 21(2), 252-273.

Smith, C. (2003). Rhetoric and Human Consciousness: A History. Prospect Heights, IL: Waveland Press.

Stark, R. (2009). Rhetoric, Science, and Magic in Seventeenth-Century England. Washington, DC: Catholic University of America Press.

Stern, B. (1988). Medieval Allegory: Roots of Advertising Strategy for the Mass Market. Journal of Marketing, 52(3), 84-94.

Stern, B. (1990). Other-speak: Classical Allegory and Contemporary Advertising. Journal of Advertising, 19(3), 14-26.

Thomas, M. J. (2006). The Malpractice of Marketing Management. Marketing Intelligence \& Planning, 24(2), 96-101.

Tom, G., and Eves, A. (1999). The Use of Rhetorical Devices in Advertising. Journal of Advertising Research, 39(4), 39-43.

Tonks, D. (2002). Marketing as Cooking: The Return of the Sophists. Journal of Marketing Management, 18(7-8), 803-822.

Varey, R. (2013). Marketing in the Flourishing Society Megatrend. Journal of Macromarketing, 33(4), 354-368.

Vargo, S. L., and Lusch, R. F. (2004). Evolving to a New Dominant Logic for Marketing. Journal of Marketing, 68(1), 1-17.

Verhoef, P. C., and Leeflang, P. S. H. (2009). Understanding the Marketing Department's Influence Within the Firm. Journal of Marketing, 73(2), 14-37.

Williams, R. (1980). Problems in Materialism and Culture. London: Verso.

Williamson, J. (2002). Decoding Advertisements: Ideology and Meaning in Advertising. London: Marion Boyars. 


\section{Introduction}

Beniger, J. (1986). The Control Revolution: Technological and Economic Origins of the Information Society. London: Harvard University Press.

Brown, S. (2002). The Spectre of Kotlerism: A Literary Appreciation. European Management Journal, 20(2), 129-146.

Brown, S. (2004). Writing Marketing: The Clause that Refreshes. Journal of Marketing Management, 20(3-4), 321-342.

Brown, S. (2005). Writing Marketing: Literary Lessons From Academic Authorities. London: Sage.

Brown, S. (2010). Where the Wild Brands Are: Some Thoughts on Anthropomorphic Marketing. The Marketing Review, 10(3), 209-224.

Bush, A. , and Boller, G. (1991). Rethinking the Role of Television Advertising During Health Crises: A Rhetorical Analysis of the Federal AIDS Campaigns. Journal of Advertising, 20(1), 28-37.

Clark, T. , Key, T. M. , Hodis, M. , and Rajaratnam, D. (2013). The Intellectual Ecology of Mainstream Marketing Research: An Inquiry Into the Place of Marketing in the Family of Business Disciplines. Journal of the Academy of Marketing Science, 42(3), 223-241.

Conley, T. (1990). Rhetoric in the European Tradition. White Plains, NY: Longman.

Daly, C. (2016). Keep Social Honest Research: Why Transparency Is Key for Brands to Help Build Trust With Consumers on Social Media. Chartered Institute of Marketing Website. https://exchange.cim.co.uk/editorial/keep-social-honest-research/ [Accessed June 24, 2016]. Greatbatch, D. , and Clark, T. (2005). Management Speak: Why We Listen to What Management Gurus Tell Us. New York: Routledge.

Hackley, C. (2001). Marketing and Social Construction: Exploring the Rhetorics of Managed Consumption. London: Routledge.

Hackley, C. (2003). 'We Are All Customers Now ...' Rhetorical Strategy and Ideological Control in Marketing Management Texts. Journal of Management Studies, 40(5), 1325-1352. Jhally, S. (1989). Advertising as Religion: The Dialectic of Technology and Magic. In L. Angus and S. Jhally (Eds.), Cultural Politics in Contemporary America. New York: Routledge, 217-229.

Kennedy, G. (1994). A New History of Classical Rhetoric. Princeton, NJ: Princeton University Press.

Lanham, R. (2006). The Economics of Attention: Style and Substance in the Age of Information. Chicago: University of Chicago Press.

Longaker, M. (2015). Rhetorical Style and Bourgeois Virtue. University Park, PA: The Pennsylvania State University Press.

McCloskey, D. (1985). The Rhetoric of Economics. Madison: University of Wisconsin Press. McQuarrie, E. F. , and Mick, D. G. (1992). On Resonance: A Critical Pluralistic Inquiry Into Advertising Rhetoric. Journal of Consumer Research, 19(2), 180-197.

McQuarrie, E. F. , and Mick, D. G. (1996). Figures of Rhetoric in Advertising Language. Journal of Consumer Research, 22(4), 424-438.

McQuarrie, E. F. , and Mick, D. G. (1999). Visual Rhetoric in Advertising: Text-interpretive, Experimental, and Reader-response Analyses. Journal of Consumer Research, 26(1), 37-54. Merlo, O. (2011). The Influence of Marketing From a Power Perspective. European Journal of Marketing, 45(7/8), 1152-1171.

Miles, C. (2013). Persuasion, Marketing Communication, and the Metaphor of Magic.

European Journal of Marketing, 47(11/12), 2002-2019.

Miles, C. (2014a). Rhetoric and the Foundation of the Service-Dominant Logic. Journal of Organizational Change Management, 27(5), 744-755.

Miles, C. (2014b). The Rhetoric of Managed Contagion: Metaphor and Agency in the Discourse of Viral Marketing. Marketing Theory, 14(1), 3-18.

Miller, C. (1990). The Rhetoric of Decision Science, or Herbert A. Simon Says. In Herbert W. Simons (Ed.), The Rhetorical Turn. Chicago: The University of Chicago Press, 162-184.

Murphy, J. , Katula, R. , and Hoppmann, M. (2014). A Synoptic History of Classical Rhetoric. London: Routledge. 
Scott, L. M. (1994). Images in Advertising: The Need for a Theory of Visual Rhetoric. Journal of Consumer Research, 21(2), 252-273.

Smith, C. (2003). Rhetoric and Human Consciousness: A History. Prospect Heights, IL: Waveland Press.

Stark, R. (2009). Rhetoric, Science, and Magic in Seventeenth-Century England.

Washington, DC: Catholic University of America Press.

Stern, B. (1988). Medieval Allegory: Roots of Advertising Strategy for the Mass Market. Journal of Marketing, 52(3), 84-94.

Stern, B. (1990). Other-speak: Classical Allegory and Contemporary Advertising. Journal of Advertising, 19(3), 14-26.

Thomas, M. J. (2006). The Malpractice of Marketing Management. Marketing Intelligence \& Planning, 24(2), 96-101.

Tom, G. , and Eves, A. (1999). The Use of Rhetorical Devices in Advertising. Journal of Advertising Research, 39(4), 39-43.

Tonks, D. (2002). Marketing as Cooking: The Return of the Sophists. Journal of Marketing Management, 18(7-8), 803-822.

Varey, R. (2013). Marketing in the Flourishing Society Megatrend. Journal of Macromarketin g, 33(4), 354-368.

Vargo, S. L. , and Lusch, R. F. (2004). Evolving to a New Dominant Logic for Marketing. Journal of Marketing, 68(1), 1-17.

Verhoef, P. C. , and Leeflang, P. S. H. (2009). Understanding the Marketing Department's Influence Within the Firm. Journal of Marketing, 73(2), 14-37.

Williams, R. (1980). Problems in Materialism and Culture. London: Verso.

Williamson, J. (2002). Decoding Advertisements: Ideology and Meaning in Advertising. London: Marion Boyars.

\section{A History of Rhetoric for Marketers}

Anonymous (trans. H. Caplan ). (1954). Rhetorica ad Herennium. London: Loeb Classical Library.

Aristotle (trans. H. C. Lawson-Tancred ). (1991). The Art of Rhetoric. London: Penguin

Books.

Banet-Weiser, S. (2012). AuthenticTM: The Politics of Ambivalence in a Brand Culture. New York: New York University Press.

Barker, H. , and Taylor, Y. (2007). Faking It: The Quest for Authenticity in Popular Music. London: W. W. Norton \& Company.

Bazerman, C. (1987). Codifying the Social Scientific Style: The APA Publication Manual as a Behaviorist Rhetoric. In J. Nelson, A. Megill, and D. McCloskey (Eds.), The Rhetoric of the Human Sciences: Language and Argument in Scholarship and Public Affairs. Madison: University of Wisconsin Press, 125-144.

Black, E. (1965). Rhetorical Criticism: A Study in Method. New York: Macmillan.

Burke, K. (1969). A Rhetoric of Motives. Berkeley, CA: University of California Press.

Campbell, J. (1987). Charles Darwin: Rhetorician of Science. In J. Nelson , A. Megill, and D. McCloskey (Eds.), The Rhetoric of the Human Sciences: Language and Argument in Scholarship and Public Affairs. Madison: University of Wisconsin Press, 69-86.

Carruthers, M. (2008). The Book of Memory: A Study of Memory in Medieval Culture.

Cambridge: Cambridge University Press.

Chomsky, N. (2012). How the World Works. London: Hamish Hamilton.

Cloud, D. , and Feyh, K. (2015). Reason in Revolt: Emotional Fidelity and Working Class

Standpoint in the 'Internationale'. Rhetoric Society Quarterly, 45(4), 300-323.

Condit, C. M. (2006). Contemporary Rhetorical Criticism: Diverse Bodies Learning New

Languages. Rhetoric Review, 25(4), 368-373.

Conley, T. (1990). Rhetoric in the European Tradition. White Plains, NY: Longman. 
Corey, D. (2015). The Sophists in Plato's Dialogues. Albany, NY: State University of New York Press.

Critser, G. (2003). Fat Land: How Americans Became the Fattest People in the World. London: Penguin.

Davis, P. , and Hersh, R. (1987). Rhetoric and Mathematics. In J. Nelson, A. Megill , and D. McCloskey (Eds.), The Rhetoric of the Human Sciences: Language and Argument in Scholarship and Public Affairs. Madison: University of Wisconsin Press, 53-68.

de Romilly, J. (1975). Magic and Rhetoric in Ancient Greece. Cambridge, MA: Harvard University Press.

Ewen, S. (1996). PR! A Social History of Spin. New York: Basic Books.

Foss, S. (2004). Rhetorical Criticism: Exploration and Practice. Long Grove, IL: Waveland Press.

Foss, S. , Foss, K. , and Trapp, R. (2002). Contemporary Perspectives on Rhetoric. Long Grove, IL: Waveland Press.

Gaines, R. (2000). Aristotle's Rhetoric and the Contemporary Arts of Practical Discourse. In A. Gross and A. Walzer (Eds.), Rereading Aristotle's Rhetoric. Carbondale: Southern Illinois University Press.

Gilmore, J. , and Pine, B. (2007). Authenticity: What Consumers Really Want. Boston: Harvard Business School Press.

Haskins, E. , and Zappen, J. (2010). Totalitarian Visual 'Monologue': Reading Soviet Posters With Bakhtin. Rhetoric Society Quarterly, 40(4), 326-359.

Kennedy, G. (1994). A New History of Classical Rhetoric. Princeton, NJ: Princeton University Press.

King, A. (2006). The State of Rhetorical Criticism. Rhetoric Review, 25(4), 365-369.

Kinneavy, J. , and Eskin, C. (2000). Kairos in Aristotle's Rhetoric. Written Communication, 17(3), 432-444.

Klamer, A. (1987). As If Economists and Their Subject Were Rational. In J. Nelson , A. Megill , and D. McCloskey (Eds.), The Rhetoric of the Human Sciences: Language and Argument in Scholarship and Public Affairs. Madison: University of Wisconsin Press, 163-183.

Klein, N. (2009). No Logo. New York: Picador.

Lakoff, G. , and Johnson, M. (2003). Metaphors We Live By. London: University of Chicago Press.

Mack, P. (2013). A History of Renaissance Rhetoric 1380-1620. Oxford: Oxford University Press.

Malkan, S. (2007). Not Just a Pretty Face: The Ugly Side of the Beauty Industry. Gabriola Island, Canada: New Society Publishers.

McCloskey, D. (1983). The Rhetoric of Economics. Journal of Economic Literature, 21(2), 481-517.

McCloskey, D. (1985). The Rhetoric of Economics. Madison: University of Wisconsin Press. McCloskey, D. (1995). Metaphors Economists Live By. Social Research, 62(2), 215-237.

Moss, M. (2013). Salt, Sugar, Fat: How the Food Giants Hooked Us. London: WH Allen.

Murphy, J. , Katula, R. , and Hoppmann, M. (2014). A Synoptic History of Classical Rhetoric. London: Routledge.

Nelson, J. , Megill, A. , and McCloskey, D. (Eds.). (1987). The Rhetoric of the Human

Sciences: Language and Argument in Scholarship and Public Affairs. Madison: University of Wisconsin Press.

Olick, J. , and Robbins, J. (1998). Social Memory Studies: From 'Collective Memory' to the Historical Sociology of Mnemonic Practices. Annual Review of Sociology, 24, 105-140.

Olson, C. (2009). Casta Painting and the Rhetorical Body. Rhetoric Society Quarterly, 39(4), 307-330.

Richards, I. A. (1924). Principles of Literary Criticism. London: Routledge and Kegan Paul. Richards, I. A. (1965). The Philosophy of Rhetoric. Oxford: Oxford University Press.

Rosaldo, R. (1987). Where Objectivity Lies: The Rhetoric of Anthropology. In J. Nelson, A. Megill , and D. McCloskey (Eds.), The Rhetoric of the Human Sciences: Language and

Argument in Scholarship and Public Affairs. Madison: University of Wisconsin Press, 87-110. 
Salek, T. (2016). The Rhetorical Form of Mia and Ronan Farrow's 2014 Online Firestorm Against \#WOODYALLEN. Communication, Culture \& Critique, 9(3), 477-494.

Schlosser, E. (2002). Fast Food Nation: What the All-American Meal Is Doing to the World. London: Penguin.

Simons, H. (Ed.). (1990a). The Rhetorical Turn: Invention and Persuasion in the Conduct of Inquiry. Chicago: University of Chicago Press.

Simons, H. (1990b). The Rhetoric of Inquiry as an Intellectual Movement. In H. Simons (Ed.), The Rhetorical Turn: Invention and Persuasion in the Conduct of Inquiry. Chicago: University of Chicago Press, 1-31.

Sipiora, P. (2002). Introduction: The Ancient Concept of Kairos. In P. Sipiora and J. Baumlin (Eds.), Rhetoric and Kairos: Essays in History, Theory, and Praxis. Albany, NY: State University of New York Press, 1-22.

Sloane, T. O. (2013). From Elocution to New Criticism: An Episode in the History of Rhetoric. Rhetorica: A Journal of the History of Rhetoric, 31(3), 297-330.

Smith, A. (2001). (ed. J. C. Bryce ). Lectures on Rhetoric and Belles Lettres. Oxford: Clarendon Press.

Smith, C. (2003). Rhetoric and Human Consciousness: A History. Prospect Heights, IL: Waveland Press.

Stark, R. (2009). Rhetoric, Science, and Magic in Seventeenth-Century England. Washington, DC: Catholic University of America Press.

Tindale, C. (2004). Rhetorical Argumentation: Principles of Theory and Practice. London: Sage.

Tindale, C. (2010). Reason's Dark Champions: Constructive Strategies of Sophistic Argument. Columbia, SC: University of South Carolina Press.

Vickers, B. (1999). In Defence of Rhetoric. Oxford: Clarendon Press.

Yates, F. (2001). The Art of Memory. Chicago: University of Chicago Press.

Zarefsky, D. (2006). Reflections on Rhetorical Criticism. Rhetoric Review, 25(4), 383-387.

\section{Marketing Scholarship and Rhetoric}

Alvesson, M. (1993). Organizations as Rhetoric-Knowledge-Intensive Firms and the Struggle With Ambiguity. Journal of Management Studies, 30(6), 997-1015.

Aristotle (trans. H. C. Lawson-Tancred ). (1991). The Art of Rhetoric. London: Penguin Books.

Ballantyne, D. (2004). Dialogue and Its Role in the Development of Relationship Specific Knowledge. Journal of Business \& Industrial Marketing, 19(2), 114-123.

Billig, M. (1985). Prejudice, Categorisation and Particularisation: From a Perceptual to a Rhetoric Account. European Journal of Social Psychology, 15(June), 79-103.

Billig, M. (1996). Arguing and Thinking: A Rhetorical Approach to Social Psychology. Cambridge: Cambridge University Press.

Billig, M. (1998). Rhetoric and the Unconscious. Argumentation, 4(6), 199-216.

Bonet, E. , and Sauquet, A. (2010). Rhetoric in Management and in Management Research. Journal of Organizational Change Management, 23(2), 120-133.

Boyd, J. , and Waymer, D. (2011). Organizational Rhetoric: A Subject of Interest(s).

Management Communication Quarterly, 25(3), 474-493.

Brown, S. (1995). The Eunuch's Tale: Reviewing Reviewed. Journal of Marketing Management, 11(7), 681-706.

Brown, S. (1999). Marketing and Literature: The Anxiety of Academic Influence. The Journal of Marketing, 63(1), 1-15.

Brown, S. (2002). The Spectre of Kotlerism: A Literary Appreciation. European Management Journal, 20(2), 129-146.

Brown, S. (2004). Writing Marketing: The Clause that Refreshes. Journal of Marketing Management, 20(3-4), 321-342. 
Brown, S. (2005). Writing Marketing: Literary Lessons From Academic Authorities. London: Sage.

Brown, S. (2007). Are We Nearly There Yet? On the Retro-Dominant Logic of Marketing. Marketing Theory, 7(3), 291-300.

Brown, S. (2010). Where the Wild Brands Are: Some Thoughts on Anthropomorphic Marketing. The Marketing Review, 10(3), 209-224.

Brownlie, D. , and Saren, M. (1992). The Four Ps of the Marketing Concept: Prescriptive, Polemical, Permanent and Problematical. European Journal of Marketing, 26(4), 34-47.

Brownlie, D. , and Saren, M. (1995). On the Commodification of Marketing Knowledge:

Opening Themes. Journal of Marketing Management, 11(7), 619-627.

Brownlie, D. , and Saren, M. (1997). Beyond the One-dimensional Marketing Manager: The Discourse of Theory, Practice and Relevance. International Journal of Research in Marketing, 14(2), 147-161.

Capelli, S. , and Jolibert, A. (2009). Metaphor's Validity in Marketing Research. Psychology and Marketing, 26(12), 1079-1090.

Cheney, G. (1983). The Rhetoric of Identification and the Study of Organizational Communication. Quarterly Journal of Speech, 69(2), 143-158.

Cheney, G. , Christensen, L. T. , Conrad, C. , and Lair, D. J. (2004). Corporate Rhetoric as Organizational Discourse. In D. Grant, C. Hardy , C. Oswick, and L. Putnam (Eds.), The SAGE Handbook of Organizational Discourse. London: Sage, 79-103.

Cornelissen, J. P. (2003). Metaphor as a Method in the Domain of Marketing. Psychology and Marketing, 20(3), 209-225.

Cornelissen, J. P. (2006). Metaphor and the Dynamics of Knowledge in Organization Theory: A Case Study of the Organizational Identity Metaphor. Journal of Management Studies, 43(June), 683-709.

Cornelissen, J. P. , and Kafouros, M. (2008). Metaphors and Theory Building in Organization Theory: What Determines the Impact of a Metaphor on Theory? British Journal of Management, 19(4), 365-379.

Duncan, T. , and Moriarty, S. E. (1998). A Communication-Based Marketing Model for Managing Relationships. Journal of Marketing, 62(2), 1-13.

Durand, J. (1987). Rhetorical Figures in the Advertising Image. In J. Umiker-Sebeok (Ed.), Marketing and Semiotics: New Directions in the Study of Signs for Sale. Berlin: Mouton de Gruyter, 295-318.

Ellis, N. , and Hopkinson, G. (2010). The Construction of Managerial Knowledge in Business Networks: Managers' Theories About Communication. Industrial Marketing Management, 39(3), 413-424.

Fairclough, N. (2013). Critical Discourse Analysis: The Critical Study of Language. London: Sage.

Foss, S. , and Griffin, C. (1995). Beyond Persuasion: A Proposal for an Invitational Rhetoric. Communication Monographs, 62, 2-18.

Fox, G. L. , Rinaldo, S. B. , and Amant, K. St. (2015). The Effects of Rhetorical Figures and Cognitive Load in Word-of-Mouth Communications. Psychology \& Marketing, 32(10), 1017-1030.

Gummesson, E. (2002). Total Relationship Marketing. Oxford: Butterworth-Heinemann. Gummesson, E. (2004). Many-to-Many Marketing. Malmö, Sweden: Liber.

Hackley, C. (2001). Marketing and Social Construction: Exploring the Rhetorics of Managed Consumption. London: Routledge.

Hackley, C. (2003). 'We Are All Customers Now ...' Rhetorical Strategy and Ideological Control in Marketing Management Texts. Journal of Management Studies, 40(5), 1325-1352.

Håkansson, H. , Harrison, D. , and Waluszewski, A. (2004). Rethinking Marketing:

Developing a New Understanding of Markets. Chichester: John Wiley \& Sons.

Hartelius, E. J. , and Browning, L. D. (2008). The Application of Rhetorical Theory in Managerial Research: A Literature Review. Management Communication Quarterly, 22(1), 13-39.

Heath, R. L. (2011). External Organizational Rhetoric: Bridging Management and Sociopolitical Discourse. Management Communication Quarterly, 25(3), 415-435. 
Hirschman, E. C. (2007). Metaphor in the Marketplace. Marketing Theory, 7(3), 227-248. Kronrod, A. , and Danziger, S. (2013). 'Wii Will Rock You!' The Use and Effect of Figurative Language in Consumer Reviews of Hedonic and Utilitarian Consumption. Journal of Consumer Research, 40(4), 726-739.

Lakoff, G. (1987). Women, Fire, and Dangerous Things: What Categories Reveal About the Mind. Chicago: University of Chicago Press.

Lakoff, G. (1993). The Contemporary Theory of Metaphor. In A. Ortony (Ed.), Metaphor and Thought. Cambridge: Cambridge University Press, 202-251.

Lakoff, G. , and Johnson, M. (1980). Conceptual Metaphor in Everyday Language. The Journal of Philosophy, 77(8), 453-486.

Lakoff, G. , and Johnson, M. (2003). Metaphors We Live By. London: University of Chicago Press.

Laufer, R. (2016). Marketing, Sophism, and Mystification. Marketing Theory, 16(3), 401-406. Laufer, R. , and Paradeise, C. ([1990] 2016). Marketing Democracy: Public Opinion and Media Formation in Democratic Societies. New Brunswick, NJ: Transaction Publishers. Lowe, S. , Ellis, N. , and Purchase, S. (2008). Rethinking Language in IMP Research: Networking Processes in Other Words. Scandinavian Journal of Management, 24(4), 295-307.

McGuire, W. J. (2000). Standing on the Shoulders of Ancients: Figurative Language. Journal of Consumer Research, 27(1), 109-114.

McQuarrie, E. F. (1989). Advertising Resonance: A Semiological Perspective. In E. C. Hirschman (Ed.), Interpretive Consumer Research. Provo, UT: Association for Consumer Research, 97-114.

McQuarrie, E. F. , and Mick, D. G. (1992). On Resonance: A Critical Pluralistic Inquiry Into Advertising Rhetoric. Journal of Consumer Research, 19(2), 180-197.

McQuarrie, E. F. , and Mick, D. G. (1996). Figures of Rhetoric in Advertising Language. Journal of Consumer Research, 22(4), 424-438.

McQuarrie, E. F. , and Mick, D. G. (1999). Visual Rhetoric in Advertising: Text-interpretive, Experimental, and Reader-response Analyses. Journal of Consumer Research, 26(1), 37-54. McQuarrie, E. F. , and Mick, D. G. (2003). Re-Inquiries: Visual and Verbal Rhetorical Figures Under Directed Processing Versus Incidental Exposure to Advertising. Journal of Consumer Research, 29(4), 579-587.

McQuarrie, E. F. , and Mick, D. G. (2009). A Laboratory Study of the Effect of Verbal Rhetoric Versus Repetition When Consumers Are Not Directed to Process Advertising. International Journal of Advertising, 28(2), 287-312.

McQuarrie, E. F. , and Phillips, B. J. (Eds.). (2007). Go Figure! New Directions in Advertising Rhetoric. London: Routledge.

Meisenbach, R. , and McMillan, J. J. (2006). Blurring the Boundries: Historical Developments and Future Directions in Organizational Rhetoric. Annals of the International Communication Association, 30(1), 99-141.

Mick, D. G. (1986). Consumer Research and Semiotics: Exploring the Morphology of Signs, Symbols, and Significance. Journal of Consumer Research, 13(2), 196-213.

Mick, D. G. (1987). Towards a Semiotics of Advertising Story Grammars. In J. UmikerSebeok (Ed.), Marketing and Semiotics: New Directions in the Study of Signs for Sale. Berlin: Mouton de Gruyter, 249-278.

Mick, D. G. (1988). Schema-theoretics and Semiotics: Toward More Holistic, Pro-grammatic Research on Marketing Communication. Semiotica, 70(1/2), 1-26.

Miles, C. (2010). Interactive Marketing: Revolution or Rhetoric? London: Routledge. Miles, C. (2013). Persuasion, Marketing Communication, and the Metaphor of Magic. European Journal of Marketing, 47(11/12), 2002-2019.

Miles, C. (2014a). Rhetoric and the Foundation of the Service-Dominant Logic. Journal of Organizational Change Management, 27(5), 744-755.

Miles, C. (2014b). The Rhetoric of Managed Contagion: Metaphor and Agency in the Discourse of Viral Marketing. Marketing Theory, 14(1), 3-18.

Miles, C. (2016). Control and the Rhetoric of Interactivity in Contemporary Advertising Theory and Practice. In J. Hamilton, R. Bodle, and E. Korin (Eds.), Explorations in Critical Studies of 
Advertising. London: Routledge, 110-123.

Miles, C. (2017). The Rhetoric of Marketing Co-Creation. In G. Siegert and B. von Rimscha (Eds.), Commercial Communication in the Digital Age-Information or Disinformation? Berlin: De Gruyter.

Morgan, G. (1992). Marketing Discourse and Practice: Towards a Critical Analysis. In M. Alvesson and H. Wilmott (Eds.), Critical Management Studies. London: Sage, 136-158. Morgan, S. E. , and Reichert, T. (1999). The Message is in the Metaphor: Assessing the Comprehension of Metaphors in Advertisements. Journal of Advertising, 28(4), 1-12.

Nilsson, T. (2006). Marketing and Classical Rhetoric. In S. Lagrosen and G. Svensson (Eds.), Marketing: Broadening the Horizons. Lund: Studentlitteratur.

Nilsson, T. (2010). The Reluctant Rhetorician: Senior Managers as Rhetoricians in a Strategic Change Context. Journal of Organizational Change Management, 23(2), 137-144.

Nilsson, T. (2015). Rhetorical Business: A Study of Marketing Work in the Spirit of Contradiction. Lund: Lund University.

O'Malley, L. , Patterson, M. , and Kelly-Holmes, H. (2008). Death of a Metaphor: Reviewing the 'Marketing as Relationships' Frame. Marketing Theory, 8(2), 167-187.

O'Shaughnessy, J. , and O'Shaughnessy, N. J. (2004). Persuasion in Advertising. New York: Routledge.

O'Shaughnessy, N. (2004). Politics and Propaganda: Weapons of Mass Seduction.

Manchester: Manchester University Press.

Phillips, B. J. , and McQuarrie, E. F. (2002). The Development, Change, and Transformation of Rhetorical Style in Magazine Advertisements 1954-1999. Journal of Advertising, 31(4), $1-13$.

Phillips, B. J. , and McQuarrie, E. F. (2004). Beyond Visual Metaphor: A New Typology of Visual Rhetoric in Advertising. Marketing Theory, 4(1), 113-136.

Phillips, B. J. , and McQuarrie, E. F. (2009). Impact of Advertising Metaphor on Consumer Belief: Delineating the Contribution of Comparison Versus Deviation Factors. Journal of Advertising, 38(1), 49-62.

Phillips, B. J. , and McQuarrie, E. F. (2010). Narrative and Persuasion in Fashion Advertising. Journal of Consumer Research, 37(3), 368-392.

Potter, J. (2005). Representing Reality: Discourse, Rhetoric and Social Construction. London: Sage.

Reddy, M. (1979). The Conduit Metaphor: A Case of Frame Conflict in Our Language About Language. In A. Ortony (Ed.), Metaphor and Thought. Cambridge: Cambridge University Press, 284-324.

Scott, L. M. (1990). Understanding Jingles and Needledrop: A Rhetorical Approach to Music in Advertising. Journal of Consumer Research, 17(2), 223-236.

Scott, L. M. (1994). Images in Advertising: The Need for a Theory of Visual Rhetoric. Journal of Consumer Research, 21(2), 252-273.

Shankar, A. , Cherrier, H. , and Canniford, R. (2006). Consumer Empowerment: A

Foucauldian Interpretation. European Journal of Marketing, 40(9/10), 1013-1030.

Sillince, J. A. A. , and Suddaby, R. (2008). Bridging Management and Communication

Scholarship. Management Communication Quarterly, 22(1), 5-12.

Skålén, P. , Fellesson, M. , and Fougère, M. (2006). The Governmentality of Marketing

Discourse. Scandinavian Journal of Management, 22(4), 275-291.

Skålén, P. , Fougère, M. , and Fellesson, M. (2008). Marketing Discourse: A Critical

Perspective. London: Routledge.

Stathakopoulos, V. , Theodorakis, I. G. , and Mastoridou, E. (2008). Visual and Verbal

Rhetoric in Advertising: The Case of 'Resonance'. International Journal of Advertising, 27(4), 629-658.

Stern, B. (1988). Medieval Allegory: Roots of Advertising Strategy for the Mass Market. Journal of Marketing, 52(3), 84-94.

Stern, B. (1990). Other-speak: Classical Allegory and Contemporary Advertising. Journal of Advertising, 19(3), 14-26.

Svensson, P. (2007). Producing Marketing: Towards a Social-phenomenology of Marketing Work. Marketing Theory, 7(3), 271-290. 
Tadajewski, M. (2006). The Ordering of Marketing Theory: The Influence of McCarthyism and the Cold War. Marketing Theory, 6(2), 163-199.

Tadajewski, M. (2010a). Critical Marketing Studies: Logical Empiricism, 'Critical

Performativity' and Marketing Practice. Marketing Theory, 10(2), 210-222.

Tadajewski, M. (2010b). Towards a History of Critical Marketing Studies. Journal of Marketing Management, 26(9-10), 773-824.

Theodorakis, I. G. , Koritos, C. , and Stathakopoulos, V. (2015). Rhetorical Maneuvers in a Controversial Tide: Assessing the Boundaries of Advertising Rhetoric. Journal of Advertising, 44(1), 14-24.

Tom, G. , and Eves, A. (1999). The Use of Rhetorical Devices in Advertising. Journal of Advertising Research, 39(4), 39-43.

Tonks, D. (2002). Marketing as Cooking: The Return of the Sophists. Journal of Marketing Management, 18(7-8), 803-822.

Umiker-Sebeok, J. (Ed.). (1987). Marketing and Semiotics: New Directions in the Study of Signs for Sale. Berlin: Mouton de Gruyter.

van Dijk, T. A. (1993). Principles of Critical Discourse Analysis. Discourse \& Society, 4(2), 249-283.

Varey, R. J. (2000). A Critical Review of Conceptions of Communication Evident in Contemporary Business and Management Literature. Journal of Communication Management, 4(4), 328-340.

Varey, R. J. (2002). Marketing Communication: Principles and Practice. London: Routledge. Varey, R. J. (2008). Marketing as an Interaction System. Australasian Marketing Journal, 27(1), 79-94.

Vargo, S. L. , and Lusch, R. F. (2004). Evolving to a New Dominant Logic for Marketing. Journal of Marketing, 68(1), 1-17.

von Koskull, C. , and Fougère, M. (2011). Service Development as Practice: A Rhetorical Analysis of Customer-related Arguments in a Service Development Project. Scandinavian Journal of Management, 27(2), 205-220.

Watson, T. J. (1995). Rhetoric, Discourse and Argument in Organizational Sense Making: A Reflexive Tale. Organisation Studies, 16(5), 805-821.

Zaltman, G. , and Coulter, R. H. (1995). Seeing the Voice of the Customer: Metaphor-Based Advertising Research. Journal of Advertising Research, 35(4), 35-51.

Zanoni, P. , and Janssens, M. (2004). Deconstructing Difference: The Rhetoric of Human Resource Managers' Diversity Discourses. Organization Studies, 25(1), 55-74.

Zbaracki, M. (1998). The Rhetoric and Reality of Total Quality Management. Administrative Science Quarterly, 43(3), 602-636.

Zwick, D. , Bonsu, S. K. , and Darmody, A. (2008). Putting Consumers to Work: 'Co-creation' and New Marketing Governmentality. Journal of Consumer Culture, 8(2), 163-196.

\section{Control and the Discourse of Marketing Science}

Achrol, R. , and Kotler, P. (2006). The Service-Dominant Logic for Marketing: A Critique. In R. Lusch and S. Vargo (Eds.), The Service-Dominant Logic of Marketing: Dialog, Debate, and Directions. Armonk, NY: M. E. Sharpe, 320-333.

Alderson, W. , and Cox, R. (1948). Towards a Theory of Marketing. Journal of Marketing, 13(October), 137-152.

AMA . (2017). Definition of Marketing. www.ama.org/AboutAMA/Pages/Definition-ofMarketing.aspx [Accessed March 6, 2017].

Anderson, L.M.T. (1994). Marketing Science: Where's the Beef? Business Horizons, 37(1), 8-16.

Anderson, P. F. (1983). Marketing, Scientific Progress, and Scientific Method. Journal of Marketing, 47(4), 18.

Anderson, P. F. (1986). On Method in Consumer Research: A Critical Relativist Perspective. Journal of Consumer Research, 13(2), 155-173. 
Anderson, P. F. (1988). Relativism Revidivus: In Defense of Critical Relativism. Journal of Consumer Research, 15(3), 403-406.

Andreasen, A. (1994). Social Marketing: Its Definition and Domain. Journal of Public Policy \& Marketing, 13(1), 108-114.

Arndt, J. (1978). How Broad Should the Marketing Concept Be? Journal of Marketing, 42(1), 101.

Bagozzi, R. P. (1975). Marketing as Exchange. Journal of Marketing, 39(4), 32-39.

Bartels, R. (1951). Can Marketing Be a Science? Journal of Marketing, 15(3), 319.

Bartels, R. (1976). The History of Marketing Thought. Columbus, OH: Grid.

Beniger, J. (1986). The Control Revolution: Technological and Economic Origins of the Information Society. London: Harvard University Press.

Brown, L. O. (1948). Toward a Profession of Marketing. Journal of Marketing, 13(1), 27-31.

Brown, S. (1996). Art or Science? Fifty Years of Marketing Debate. Journal of Marketing Management, 12, 243-267.

Brown, S. (2002). The Spectre of Kotlerism: A Literary Appreciation. European Management Journal, 20(2), 129-146.

Buzzell, R. D. (1963). Is Marketing a Science? Harvard Business Review, 40(1), 32-40, 166-170.

Cassels, J. M. (1936). The Significance of Early Economic Thought on Marketing. Journal of Marketing, 1(2), 129-133.

Cialdini, R. (2001). Influence: Science and Practice. London: Allyn and Bacon.

Converse, P. D. (1945). The Development of the Science of Marketing-An Exploratory

Survey. Journal of Marketing, 10(July), 14-23.

Durkheim, E. ([1959] 2009). Socialism and Saint Simon (trans. C. Sattler ). London:

Routledge.

Fisk, G. (1967). Marketing Systems: An Introductory Analysis. London: Harper \& Row.

Funk, C. , and Rainie, L. (2015). Public and Scientists' Views on Science and Society. Pew

Research Center. www.pewinternet.org/2015/01/29/public-and-scientists-views-on-scienceand-society/ [Accessed February 15, 2017].

Gordon, R. A. , and Howell, J. E. (1959). Higher Education for Business. New York: Columbia University Press.

Hagerty, J. E. (1936). Experiences of an Early Marketing Teacher. Journal of Marketing, 1(1), 20.

Hubbard, R. (2005). Examining the Influence of Articles Involving Marketing History, Thought, and Theory: A Journal of Marketing Citation Analysis, 1950s-1990s. Marketing Theory, 5(3), 323-336.

Hunt, S. D. (1976). The Nature and Scope of Marketing. The Journal of Marketing, 40(July), 17-28.

Hunt, S. D. (1984). Should Marketing Adopt Relativism. In P. F. Anderson and M. J. Ryan (Eds.), Scientific Method in Marketing. Chicago: American Marketing Association.

Hunt, S. D. (1990). Truth in Marketing Theory and Research. Journal of Marketing, 54(July), 1-15.

Hunt, S. D. (1994). On Rethinking Marketing: Our Discipline, Our Practice, Our Methods. European Journal of Marketing, 28(3), 13-25.

Hunt, S. D. (2002). Foundations in Marketing Theory: Toward a General Theory of Marketing. Armonk, NY: M. E. Sharpe.

Hunt, S. D. (2003). Controversy in Marketing Theory: For Reason, Realism, Truth, and Objectivity. Armonk, NY: M. E. Sharpe.

Hunt, S. D. (2012). Toward the Institutionalization of Macromarketing: Sustainable Enterprise, Sustainable Marketing, Sustainable Development, and the Sustainable Society. Journal of Macromarketing, 32(4), 404-411.

Hunt, S. D. , and Edison, S. (1995). On the Marketing of Marketing Knowledge. Journal of Marketing Management, 11(December), 635-640.

Hutchinson, K. D. (1952). Marketing As a Science: An Appraisal. Journal of Marketing, 16(4), 286-293. 
Jones, D. G. B. , and Monieson, D. D. (1990). Early Development of the Philosophy of Marketing Thought. Journal of Marketing, 54(January), 102-113.

Kavanagh, D. (1994). Hunt Versus Anderson: Round 16. European Journal of Marketing, 28(3), 26-41.

Kelley, W. T. (1956). The Development of Early Thought in Marketing and Promotion. The Journal of Marketing, II, 62-67.

Kerin, R. (1996). In Pursuit of an Ideal: The Editorial and Literary History of the Journal of Marketing. Journal of Marketing, 60(1), 1-13.

Kiel, D. L. , Lusch, R. F. , and Schumacher, B. G. (1992). Toward a New Paradigm for Marketing: The Evolutionary Exchange Paradigm. Behavioral Science, 37(1), 59-76.

Kotler, P. (1972). A Generic Concept of Marketing. Journal of Marketing, 36(April), 46-54.

Kotler, P. , and Keller, K. L. (2015). Marketing Management. Boston: Pearson.

Kotler, P. , and Levy, S. J. (1969a). Broadening the Concept of Marketing. Journal of

Marketing, 33(1), 10-15.

Kotler, P. , and Levy, S. J. (1969b). A New Form of Marketing Myopia: Rejoinder to Professor Luck. Journal of Marketing, (July), 55-57.

Levy, S. J. (1959). Symbols for Sale. Harvard Business Review, 37(4), 117-124.

Luck, D. (1969). Broadening the Concept of Marketing-Too Far. Journal of Marketing, 33(July), 53-63.

Luck, D. (1974). Social Marketing: Confusion Compounded. Journal of Marketing, 35(July), 70-72.

Lusch, R. F. (2007). Marketing's Evolving Identity: Defining Our Future. Journal of Public Policy \& Marketing, 26(2), 261-268.

Lusch, R. F. , and Vargo, S. L. (2006). Service-dominant Logic: Reactions, Reflections and Refinements. Marketing Theory, 6(3), 281-288.

Lusch, R. F. , and Vargo, S. L. (2011). Service-dominant Logic: A Necessary Step. European Journal of Marketing, 45(7/8), 1298-1309.

Lusch, R. F. , and Vargo, S. L. (2012). The Forum on Markets and Marketing (FMM):

Advancing Service-dominant Logic. Marketing Theory, 12(2), 193-199.

Lusch, R. F. , and Vargo, S. L. (2014). Service-Dominant Logic: Premises, Perspectives, Possibilities. Cambridge: Cambridge University Press.

Mcgarry, E. D. (1936). The Importance of Scientific Method in Advertising. Journal of Marketing, 1, 82-86.

Miles, C. (2014). Rhetoric and the Foundation of the Service-Dominant Logic. Journal of Organizational Change Management, 27(5), 744-755.

Miles, C. (2016). Control and the Rhetoric of Interactivity in Contemporary Advertising Theory and Practice. In J. Hamilton, R. Bodle, and E. Korin (Eds.), Explorations in Critical Studies of Advertising. London: Routledge, 110-123.

Miles, C. (2018). Service-Dominant Logic-The Evolution of a Universal Marketing Rhetoric. In M. Tadajewski , M. Higgins , J. Denegri-Knott , and R. Varman (Eds.), The Routledge Companion to Critical Marketing. London: Routledge.

O'Shaughnessy, J. , and O'Shaughnessy, N. J. (2009). The Service-dominant Perspective: A Backward Step? European Journal of Marketing, 43(5/6), 784-793.

O'Shaughnessy, J. , and O'Shaughnessy, N. J. (2011). Service-dominant Logic: A Rejoinder to Lusch and Vargo's Reply. European Journal of Marketing, 45(7/8), 1310-1318.

Pierson, G. W. (1959). The Education of American Businessmen. New York: McGraw-Hill. Prahalad, C. , and Ramaswamy, V. (2004). The Future of Competition: Co-Creating Unique Value With Consumers. Boston: Harvard Business School Press.

Seelye, A. L. (1947). The Importance of Economic Theory in Marketing Courses. Journal of Marketing, 11(2), 223-227.

Shaw, A. W. (1912). Some Problems in Market Distribution. Quarterly Journal of Economics, 26, 703-765.

Sheth, J. N. , and Uslay, C. (2007). Implications of the Revised Definition of Marketing: From Exchange to Value Creation. Journal of Public Policy \& Marketing, 26(2), 302-307.

Simon, H. (1996). The Sciences of the Artificial. Cambridge, MA: The MIT Press. 
Steiner, R. L. (1976). The Prejudice Against Marketing. Journal of Marketing, 40(3), 2-9. Tadajewski, M. (2006a). The Ordering of Marketing Theory: The Influence of McCarthyism and the Cold War. Marketing Theory, 6(2), 163-199.

Tadajewski, M. (2006b). Remembering Motivation Research: Toward an Alternative Genealogy of Interpretive Consumer Research. Marketing Theory, 6(4), 429-466.

Tadajewski, M. (2016). Academic Labour, Journal Ranking Lists and the Politics of Knowledge Production in Marketing. Journal of Marketing Management, 32(1-2), 1-18. Thomson, E. M. , and Adams, H. F. (1996). 'The Science of Publicity' an American Advertising Theory, 1900-1920. Journal of Design History, 9(4), 253-272.

Vargo, S. L. , and Lusch, R. F. (2004). Evolving to a New Dominant Logic for Marketing. Journal of Marketing, 68(1), 1-17.

Vargo, S. L. , and Lusch, R. F. (2008). Service-dominant Logic: Continuing the Evolution. Journal of the Academy of Marketing Science, 36(1), 1-10.

Vargo, S. L. , and Lusch, R. F. (2011). It's All B2B ... and Beyond: Toward a Systems Perspective of the Market. Industrial Marketing Management, 40(February), 181-187. Vargo, S. L. , and Lusch, R. F. (2015). Institutions and Axioms: An Extension and Update of Service-Dominant Logic. Journal of the Academy of Marketing Science, 1-19.

Vargo, S. L. , and Lusch, R. F. (2016). Service-dominant Logic 2025. International Journal of Research in Marketing (In Press, Accepted Manuscript).

http://doi.org/10.1016/j.jiresmar.2016.11.001

Wilkie, W. L. , and Moore, E. S. (2003). Scholarly Research in Marketing: Exploring the '4 Eras' of Thought Development. Journal of Public Policy \& Marketing, 22(2), 116-146. Wilkie, W. L. , and Moore, E. S. (2006). Macromarketing as a Pillar of Marketing Thought. Journal of Macromarketing, 26(1), 224-232.

\section{A Rhetorical Approach to Marketing as Exchange}

Ashby, W. R. (1957). An Introduction to Cybernetics. London: Chapman \& Hall.

Bateson, G. (2000). Steps to an Ecology of Mind. Chicago: University of Chicago Press.

Beer, S. (1993). Designing Freedom. Toronto: House of Anansi Press.

Beer, S. (1994). Decision and Control: The Meaning of Operational Research and Management Cybernetics. Chichester: John Wiley \& Sons.

Beer, S. (1995). Brain of the Firm. Chichester: John Wiley \& Sons.

Beniger, J. (1986). The Control Revolution: Technological and Economic Origins of the Information Society. London: Harvard University Press.

Critser, G. (2003). Fat Land: How Americans Became the Fattest People in the World. London: Penguin.

Davenport, T. , and Beck, J. (2001). The Attention Economy: Understanding the New Currency of Business. Boston: Harvard Business School Press.

Dixon, D. F. (1995). Retailing in Classical Athens: Gleanings From Contemporary Literature and Art. Journal of Macromarketing, 15(1), 74-85.

Ewen, S. (2001). Captains of Consciousness: Advertising and the Social Roots of the Consumer Culture. New York: Basic Books.

Klein, N. (2009). No Logo. New York: Picador.

Kotler, P. (1972). A Generic Concept of Marketing. Journal of Marketing, 36(April), 46-54.

Kotler, P. , and Zaltman, G. (1971). Social Marketing: An Approach to Planned Social

Change. Journal of Marketing, 35(3), 3-12.

Lanham, R. (2006). The Economics of Attention: Style and Substance in the Age of

Information. Chicago: University of Chicago Press.

Lanning, M. J. , and Michaels, E. G. (1988). A Business Is a Value Delivery System.

McKinsey Staff Paper (No. 41, July), 1-16.

Levine, R. , Locke, C. , Searls, D. , and Weinberger, D. (2000). The Cluetrain Manifesto: The End of Business as Usual. Harlow: Pearson Education. 
Malkan, S. (2007). Not Just a Pretty Face: The Ugly Side of the Beauty Industry. Gabriola Island, Canada: New Society Publishers.

Maslow, A. H. (1943). A Theory of Human Motivation. Psychological Review, 50(4), 370-396. McCloskey, D. (1995). Metaphors Economists Live By. Social Research, 62(2), 215-237. Mitchell, A. (1999). Out of the Shadows. Journal of Marketing Management, 15(1-3), $25-42$. Moore, K. R. (2014). Plato's Puppets of the Gods: Representing the Magical, the Mystical and the Metaphysical. Arion, 22(2), 37-72.

Moss, M. (2013). Salt, Sugar, Fat: How the Food Giants Hooked Us. London: WH Allen. Prahalad, C. , and Ramaswamy, V. (2004). The Future of Competition: Co-Creating Unique Value With Consumers. Boston: Harvard Business School Press.

Ries, A. , and Trout, J. (2001). Positioning: The Battle for Your Mind. London: McGraw-Hill. Schlosser, E. (2002). Fast Food Nation: What the All-American Meal Is Doing to the World. London: Penguin.

Shaw, E. H. (1995). The First Dialogue on Macromarketing. Journal of Macromarketing, 15(1), 7-20.

Vargo, S. L. , and Lusch, R. F. (2004). Evolving to a New Dominant Logic for Marketing. Journal of Marketing, 68(1), 1-17.

Weinstein, J. (2009). The Market in Plato's Republic. Classical Philology, 104(4), 439-458. Wu, T. (2016). The Attention Merchants. London: Atlantic Books.

\section{Marketing and Sophism-A Comparison}

Anderson, P. F. (1983). Marketing, Scientific Progress, and Scientific Method. Journal of Marketing, 47(4), 18.

Anderson, P. F. (1986). On Method in Consumer Research: A Critical Relativist Perspective. Journal of Consumer Research, 13(2), 155-173.

Anderson, P. F. (1988). Relativism Revidivus: In Defense of Critical Relativism. Journal of Consumer Research, 15(3), 403-406.

Aristotle (trans. H. C. Lawson-Tancred ) (1991). The Art of Rhetoric. London: Penguin Books.

Baker, S. (1999). Five Baselines for Justification in Persuasion. Journal of Mass Media Ethics, 14, 69-81.

Barksdale, H. C. , and Darden, W. R. (1972). Consumer Attitudes Toward Marketing and Consumerism. Journal of Marketing, 36(4), 28-35.

Chan, T.-S. , and Cui, G. (2004). Consumer Attitudes Toward Marketing in a Transitional Economy. A Replication and Extension. Journal of Consumer Marketing, 21(1), 10-26.

Chomsky, N. (2012). How the World Works. London: Hamish Hamilton.

Cluley, R. (2016). The Depiction of Marketing and Marketers in the News Media. European Journal of Marketing, 50(4), 752-769.

Cole, T. (1991). The Origins of Rhetoric in Ancient Greece. Baltimore: John Hopkins University Press.

Conley, T. (1990). Rhetoric in the European Tradition. White Plains, NY: Longman.

Corey, D. (2015). The Sophists in Plato's Dialogues. Albany, NY: State University of New York Press.

Edelman . (2017). Edelman Trust Barometer 2017-UK Findings.

www.edelman.co.uk/magazine/posts/edelman-trust-barometer-2017-uk-findings/ [Accessed July 25, 2017].

Ferdous, A. S. , and Towfique, B. (2008). Consumer Sentiment Towards Marketing in Bangladesh: The Relationship Between Attitudes to Marketing, Satisfaction and Regulation. Marketing Intelligence \& Planning, 26(5), 481-495.

Gagarin, M. (2002). Antiphon the Athenian: Oratory, Law, and Justice in the Age If the Sophists. Austin: University of Texas Press.

Gallup . (2015). Honesty/Ethics in Professions. www.gallup.com/poll/1654/honesty-ethicsprofessions.aspx [Accessed July 25, 2017]. 
Garver, E. (2009). Aristotle on the Kinds of Rhetoric. Rhetorica: A Journal of the History of Rhetoric, 27(1), 1-18.

Gaski, J. , and Etzel, M. (1986). The Index of Consumer Sentiment Toward Marketing. Journal of Marketing, 50(3), 71-81.

Gaski, J. , and Etzel, M. (2005). National Aggregate Consumer Sentiment Toward Marketing: A Thirty-year Retrospective and Analysis. Journal of Consumer Research, 31(4), 859-868.

Heath, T. P. M. , and Heath, M. (2008). (Mis)trust in Marketing: A Reflection on Consumers' Attitudes and Perceptions. Journal of Marketing Management, 24(9-10), 1025-1039.

Hunt, S. D. (1990). Truth in Marketing Theory and Research. Journal of Marketing, 54(July), 1-15.

Hunt, S. D. (1994). On Rethinking Marketing: Our Discipline, Our Practice, Our Methods. European Journal of Marketing, 28(3), 13-25.

Hunt, S. D. (2002). Foundations in Marketing Theory: Toward a General Theory of Marketing. Armonk, NY: M. E. Sharpe.

Hunt, S. D. (2003). Controversy in Marketing Theory: For Reason, Realism, Truth, and Objectivity. Armonk, NY: M. E. Sharpe.

Hunt, S. D. , and Edison, S. (1995). On the Marketing of Marketing Knowledge. Journal of Marketing Management, 11(December), 635-640.

Kennedy, G. (1994). A New History of Classical Rhetoric. Princeton, NJ: Princeton University Press.

Keys, W. B. (1973). Subliminal Seduction. Englewood Cliffs, NJ: Prentice-Hall.

Lanning, M. J. , and Michaels, E. G. (1988). A Business Is a Value Delivery System.

McKinsey Staff Paper (No. 41, July), 1-16.

Lavery, J. (2008). Protagoras. In P. O'Grady (Ed.), The Sophists: An Introduction. London:

Duckworth, 30-44.

Laufer, R. , and Paradeise, C. ([1990] 2016). Marketing Democracy: Public Opinion and Media Formation in Democratic Societies. New Brunswick, NJ: Transaction Publishers.

Lawson, R. , Todd, S. , and Boshoff, C. (2001). Relationships Between Consumer Sentiment Towards Marketing and Consumer Lifestyles. Australasian Marketing Journal, 9(2), 7-22.

Longaker, M. , and Walker, J. (2011). Rhetorical Analysis: A Brief Guide for Writers. Boston: Longman.

Lysonski, S. , Durvasula, S. , and Watson, J. (2003). Should Marketing Managers Be Concerned About Attitudes Towards Marketing and Consumerism in New Zealand? A Longitudinal View. European Journal of Marketing, 37(3/4), 385-406.

Marsh, C. (2001). Public Relations Ethics: Contrasting Models From the Rhetorics of Plato, Aristotle, and Isocrates. Journal of Mass Media Ethics, 16(2), 78-98.

Marsh, C. (2007). Aristotelian Causal Analysis and Creativity in Copywriting: Toward a Rapprochement Between Rhetoric and Advertising. Written Communication, 24(2), 168-187. Marsh, C. (2013). Classical Rhetoric and Modern Public Relations. London: Routledge. McKenna, S. (1999). Advertising as Epideictic Rhetoric. In C. Jan Swearingen and D. S. Kaufer (Eds.), Rhetoric, the Polis, and the Global Village: Selected Papers From the 1998 Thirtieth Anniversary Rhetoric Society of America. London: Lawrence Erlbaum Associates, 103-109.

Packard, V. (1957). The Hidden Persuaders. New York: McKay.

Pollay, R. W. (1986). The Distorted Mirror: Reflections on the Unintended Consequences of Advertising. Journal of Marketing, 50(2), 18-36.

Sheth, J. N. , and Sisodia, R. S. (Eds.). (2006a). Does Marketing Need Reform? Fresh Perspectives on the Future. London: Routledge.

Sheth, J. N. , and Sisodia, R. S. (2006b). Introduction. In J. N. Sheth and R. S. Sisodia (Eds.), Does Marketing Need Reform? Fresh Perspectives on the Future. London: Routledge, 3-11.

Tell, H. (2011). Plato's Counterfeit Sophists. Washington, DC: Center for Hellenic Studies. Tonks, D. (2002). Marketing as Cooking: The Return of the Sophists. Journal of Marketing Management, 18(7-8), 803-822.

Varadarajan, P. R. , and Thirunarayana, P. N. (1990). Consumers' Attitudes Towards Marketing Practices, Consumerism and Government Regulations: Cross-national 
Perspectives. European Journal of Marketing, 24(6), 6-23.

Webster, C. (1991). Attitudes Toward Marketing Practices: The Effects of Ethnic Identification. Journal of Applied Business Research, 7(2), 107-116.

Wee, C.-H. , and Chan, M. (1989). Consumer Sentiment Towards Marketing in Hong Kong. European Journal of Marketing, 23(4), 25-39.

\section{Magic, Sympathy, and Language}

Agrippa, C. ([1651] 1898). Three Books of Occult Philosophy or Magic-Book One-Natural Magic (trans. J. Freake ; Ed. By W. Whitehead ). Chicago: Hahn \& Whitehead.

Albas, D. , and Albas, C. (1989). Modern Magic: The Case of Examinations. The Sociological Quarterly, 30(4), 603-613.

Arbatel . ([1655, trans. Robert Turner ] 1978). Of Magic. London: Askin.

Austin, J. (1962). How to Do Things With Words. Oxford: Clarendon Press.

Bailey, M. (2006). The Meanings of Magic. Magic, Ritual, and Witchcraft, 1(1), 1-23.

Bremmer, J. N. (1999). The Birth of the Term 'Magic'. Zeitschrift Für Papyrologie Und Epigraphik, 126, 1-12.

Chlup, R. (2007). The Ritualization of Language in the Hermetica . Aries, 7(2), 133-159.

Collins, D. (2003). Nature, Cause, and Agency in Greek Magic. Transactions of the American Philological Association, 133(1), 17-49.

Evans-Pritchard, E. (1929). The Morphology and Function of Magic. American

Anthropologist, 31, 619-641.

Frazer, J. (1894). The Golden Bough: A Study in Comparative Religion. First Edition. New York: Macmillan (Digital Archive Version). https://archive.org/details/goldenboughstudy01fraz [Accessed August 2, 2017].

Frazer, J. (1920). The Golden Bough: A Study in Magic and Religion. Part 1, Vol. 1. Third Edition. London: Macmillan (Digital Archive Version).

https://archive.org/details/TheGoldenBough-Part1-

TheMagicArtAndTheEvolutionOfKingsVol.1 [Accessed August 20, 2017].

Geertz, H. (1975). An Anthropology of Religion and Magic, I. The Journal of Interdisciplinary History, 6(1), 71-89.

Greenwood, S. (2000). Magic, Witchcraft and the Otherworld: An Anthropology. Oxford: Berg Oxford.

Hammond, D. (1970). Magic: A Problem in Semantics. American Anthropologist, 72(6), 1349-1356.

Lehrich, C. (2007). The Occult Mind: Magic in Theory and Practice. Ithaca: Cornell University Press.

Malinowski, B. (1935). Coral Gardens and Their Magic. New York, NY: American Book Co. Smith, J. (2004). Relating Religion: Essays in the Study of Religion. Chicago: University of Chicago Press.

Stark, R. (2001). Reconceptualizing Religion, Magic, and Science. Review of Religious Research, 43(2), 101-120.

Tambiah, S. (1968). The Magical Power of Words. Man, 3(2), 175-208.

Tambiah, S. (1979). A Performative Approach to Ritual. Proceedings of the British Academy, 65, 113-169.

Tonks, D. (2002). Marketing as Cooking: The Return of the Sophists. Journal of Marketing Management, 18(7-8), 803-822.

Wax, M. , and Wax, R. (1963). The Notion of Magic. Current Anthropology, 4(5), 495-518.

Yates, F. (2003). The Occult Philosophy in the Elizabethan Age. London: Routledge. 


\section{The Magical Roots of Rhetoric}

Burke, K. (1969). A Rhetoric of Motives. Berkeley, CA: University of California Press. Cassin, B. (2014). Sophistical Practice: Towards a Consistent Relativism. Oxford: Oxford University Press.

Cole, T. (1995). The Origins of Rhetoric in Ancient Greece. Baltimore: John Hopkins University Press.

Covino, W. A. (1992). Magic And/As Rhetoric: Outlines of a History of Phantasy. Journal of Advanced Composition, 12(2), 349-358.

Covino, W. A. (1994). Magic, Rhetoric, and Literacy: An Eccentric History of the Composing Imagination. Albany, NY: State University of New York Press.

de Romilly, J. (1975). Magic and Rhetoric in Ancient Greece. Cambridge, MA: Harvard University Press.

Dylan, J. , and Gergel, T. (2003). The Greek Sophists. London: Penguin.

Kingsley, P. (1996). Ancient Philosophy, Mystery, and Magic: Empedocles and Pythagorean Tradition. Oxford: Oxford University Press.

Lombardo, S. (trans.). (2010). Parmenides and Empedocles: The Fragments in Verse Translation. Eugene, OR: Wipf \& Stock.

Moore, K. R. (2014). Plato's Puppets of the Gods: Representing the Magical, the Mystical and the Metaphysical. Arion, 22(2), 37-72.

O'Keefe, D. (1983). Stolen Lightning: The Social Theory of Magic. New York: Vintage. Schiappa, E. (1990). Did Plato Coin Rhetorike? American Journal of Philology, 111(4), 457-470.

Stark, R. (2009). Rhetoric, Science, and Magic in Seventeenth-Century England.

Washington, DC: Catholic University of America Press.

Vickers, B. (1986). Analogy Versus Identity: The Rejection of Occult Symbolism, 1580-1680.

In B. Vickers (Ed.), Occult and Scientific Mentalities in the Renaissance. Cambridge:

Cambridge University Press, 95-163.

Ward, J. O. (1988). Magic and Rhetoric From Antiquity to the Renaissance: Some Ruminations. Rhetorica, 6(1), 57-118.

Wardy, R. (2005). The Birth of Rhetoric: Gorgias, Plato and Their Successors. London: Routledge.

\section{Magical Persuasion and Marketing}

Ankerloo, B. , and Clark, S. (Eds.). (2002). Witchcraft and Magic in Europe: The Period of the Witch Trials. London: The Athlone Press.

Arnould, E. J. , and Price, L. L. (1993). River Magic: Extraordinary Experience and the Extended Service Encounter. Journal of Consumer Research, 20(1), 24-45.

Arnould, E. J. , Price, L. L. , and Otnes, C. (1999). Making (Consumption) Magic: A Study of White-Water River Rafting. Journal of Contemporary Ethnography, 28(1), 33-68.

Belk, R. (1988). Possessions and the Extended Self. Journal of Consumer Research, 15(2), 139.

Belk, R. (1991). The Ineluctable Mysteries of Possessions. Journal of Social Behavior \& Personality, 6(6), 17-55.

Belk, R. , Ger, G. , and Askegaard, S. (2003). The Fire of Desire: A Multisited Inquiry Into Consumer Passion. Journal of Consumer Research, 30(December), 326-351.

Belk, R. , Wallendorf, M. , and Sherry Jr, J. (1989). The Sacred and the Profane in Consumer Behavior: Theodicy on the Odyssey. Journal of Consumer Research, 16(June), 1-38. 
Brown, S. (2009). Double, Double Toil and Trouble: On the Equivocal Magic of Marketing. Journal of Customer Behaviour, 8(2), 163-175.

Campbell, C. (2005). The Craft Consumer. Journal of Consumer Culture, 5(1), 23-42.

Cassin, B. (2014). Sophistical Practice: Towards a Consistent Relativism. Oxford: Oxford University Press.

Dégh, L. (1994). American Folklore and the Mass Media. Bloomington: Indiana University Press.

Erikson, E. (1982). The Life Cycle Completed. New York: W.W. Norton.

Fernandez, K. , and Lastovicka, J. (2011). Making Magic: Fetishes in Contemporary

Consumption. Journal of Consumer Research, 38(2), 278-299.

Gmelch, G. (2012). Baseball Magic. In J. Spradley and D. McCurdy (Eds.), Conformity and Conflict. Upper Saddle River, NJ: Prentice-Hall, 266-274.

Goffman, E. (1990). The Presentation of Self in Everyday Life. London: Penguin.

Gossage, H. L. (1967). The Gilded Bough: Magic and Advertising. In F. Matson and A.

Montagu (Eds.), The Human Dialogue: Perspectives on Communication. New York: Free Press, 363-370.

Harré, R. (1985). Situational Rhetoric and Self-Presentation. In J. P. Forgas (Ed.), Language and Social Situations. Springer Series in Social Psychology. New York, NY: Springer.

Jhally, S. (1989). Advertising as Religion: The Dialectic of Technology and Magic. In L. Angus and S. Jhally (Eds.), Cultural Politics in Contemporary America. New York: Routledge, 217-229.

Jhally, S. (1990). The Codes of Advertising: Fetishism and the Political Economy of Meaning in the Consumer Society. New York: Routledge.

Laufer, R. , and Paradeise, C. ([1990] 2016). Marketing Democracy: Public Opinion and Media Formation in Democratic Societies. New Brunswick, NJ: Transaction Publishers.

Leiss, W. , Kline, S. , and Jhally, S. (1997). Social Communication in Advertising: Persons, Products, \& Images of Well-Being. London: Routledge.

Levi-Strauss, C. (1973). Totemism. London: Penguin University Books.

Levy, S. J. (1999). Brands, Consumers, Symbols, and Research: Sidney J. Levy on Marketing. Thousand Oaks, CA: Sage.

Muñiz Jr, A. , and Schau, H. (2005). Religiosity in the Abandoned Apple Newton Brand Community. Journal of Consumer Research, 31(4), 737-747.

Newman, G. , Diesendruck, G. , and Bloom, P. (2011). Celebrity Contagion and the Value of Objects. Journal of Consumer Research, 38(2), 215-228.

Nienkamp, J. (2001). Internal Rhetorics: Towards a History and Theory of Self-Persuasion. Carbondale and Edwardsville: Southern Illinois University Press.

Pollay, R. W. (1986). The Distorted Mirror: Reflections on the Unintended Consequences of Advertising. Journal of Marketing, 50(2), 18-36.

Rook, D. W. (1985). The Ritual Dimension of Consumer Behavior. Journal of Consumer Research, 12(3), 251-264.

Rook, D. W. (1987). Modern Hex Signs and Symbols of Security. In J. Umiker-Sebeok (Ed.), Marketing and Semiotics: New Directions in the Study of Signs for Sale. Berlin: Mouton de Gruyter, 239-246.

Schnoebelen, J. (2009). Witchcraft Allegations, Refugee Protection and Human Rights: A Review of the Evidence. New Issues in Refugee Research, Paper 169. Geneva: UNHCR. Sheffield, T. (2006). The Religious Dimensions of Advertising. New York: Palgrave Macmillan.

Slater, D. (1997). Consumer Culture and Modernity. Cambridge: Polity Press.

St. James, Y. , Handelman, J. M. , and Taylor, S. F. (2011). Magical Thinking and Consumer Coping. Journal of Consumer Research, 38(4), 632-649.

Thomas, K. (1991). Religion and the Decline of Magic. London: Penguin.

Umiker-Sebeok, J. (Ed.). (1987). Marketing and Semiotics: New Directions in the Study of Signs for Sale. Berlin: Mouton de Gruyter.

Vargo, S. L. , and Lusch, R. F. (2004). Evolving to a New Dominant Logic for Marketing. Journal of Marketing, 68(1), 1-17. 
Ward, J. O. (1988). Magic and Rhetoric From Antiquity to the Renaissance: Some

Ruminations. Rhetorica, 6(1), 57-118.

Wardy, R. (2005). The Birth of Rhetoric: Gorgias, Plato and Their Successors. London:

Routledge.

Williams, R. (1980). Problems in Materialism and Culture. London: Verso.

Williamson, J. ([1978] 2002). Decoding Advertisements: Ideology and Meaning in Advertising. London: Marion Boyars.

\section{A Sophistic Marketing}

AMA Task Force on the Development of Marketing Thought . (1988). Developing, Disseminating, and Utilizing Marketing Knowledge. Journal of Marketing, 52(October), 1-25.

Ballantyne, D. , Frow, P. , Varey, R. , and Payne, A. (2011). Value Propositions as Communication Practice: Taking a Wider View. Industrial Marketing Management, 40(2), 202-210.

Brehm, J. , and Cole, A. (1966). Effect of a Favor Which Reduces Freedom. Journal of Personality and Social Psychology, 3(4), 420-426.

Brehm, J. , and Sensenig, J. (1966). Social Influence as a Function of Attempted and Implied Usurpation of Choice. Journal of Personality and Social Psychology, 4(6), 703-707.

Brown, S. (2009). Double, Double Toil and Trouble: On the Equivocal Magic of Marketing. Journal of Customer Behaviour, 8(2), 163-175.

Cassin, B. (2014). Sophistical Practice: Towards a Consistent Relativism. Oxford: Oxford University Press.

Clark, T. , Key, T. M. , Hodis, M. , and Rajaratnam, D. (2013). The Intellectual Ecology of Mainstream Marketing Research: An Inquiry Into the Place of Marketing in the Family of Business Disciplines. Journal of the Academy of Marketing Science, 42(3), 223-241. Cohen, W. (2006). The Marketing Plan. Hoboken, NJ: John Wiley \& Sons.

de Chernatony, L. (2009). Towards the Holy Grail of Defining 'Brand'. Marketing Theory, 9(1), 101-105.

Dillon, J. , and Gergel, T. (2003). The Greek Sophists. London: Penguin.

Duncan, T. , and Moriarty, S. E. (1998). A Communication-Based Marketing Model for Managing Relationships. Journal of Marketing, 62(2), 1-13.

Finne, A.. , and Grönroos, C. (2009). Rethinking Marketing Communication: From Integrated Marketing Communication to Relationship Communication. Journal of Marketing Communications , 15(2), 179-195.

Grönroos, C. (2000). Creating a Relationship Dialogue: Communication, Interaction and Value. The Marketing Review, 1(1), 5-14.

Gummesson, E. (2002). Total Relationship Marketing. Oxford: Butterworth-Heinemann. Gummesson, E. (2008). Customer Centricity: Reality or a Wild Goose Chase? European Business Review, 20(4), 315-330.

Hawhee, D. (2004). Bodily Arts: Rhetoric and Athletics in Ancient Greece. Austin: University of Texas Press.

Hill, M. E. , McGinnis, J. , and Cromartie, J. (2007). A Marketing Paradox. Marketing Intelligence \& Planning, 25(7), 652-661.

Holbrook, M. B. (2003). Adventures in Complexity: An Essay on Dynamic Open Complex Adaptive Systems, Butterfly Effects, Self-Organizing Order, Coevolution, the Ecological Perspective, Fitness Landscapes, Market Spaces, Emergent Beauty at the Edge of Chaos, and All that Jazz. Academy of Marketing Science Review, 2003(6).

Horberry, R. , and Lingwood, G. (2014). Read Me. London: Laurence King.

Jarratt, S. (1998). Rereading the Sophists: Classical Rhetoric Refigured. Carbondale, IL: Southern Illinois University Press.

Jhally, S. (1989). Advertising as Religion: The Dialectic of Technology and Magic. In L. Angus and S. Jhally (Eds.), Cultural Politics in Contemporary America. New York: Routledge,

217-229. 
Jhally, S. (1990). The Codes of Advertising: Fetishism and the Political Economy of Meaning in the Consumer Society. New York: Routledge.

Kotler, P. , and Keller, K. L. (2015). Marketing Management. Boston: Pearson.

Lee, N. , and Greenley, G. (2010). The Theory-Practice Divide: Thoughts From the Editors and Senior Advisory Board of EJM. European Journal of Marketing, 44(1/2), 5-20.

Lehmann, D. , McAlister, L. , and Staelin, R. (2011). Sophistication in Research in Marketing. Journal of Marketing, 75(July), 155-165.

Lindberg-Repo, K. , and Grönroos, C. (2004). Conceptualising Communications Strategy

From a Relational Perspective. Industrial Marketing Management, 33(3), 229-239.

Lusch, R. F. , and Vargo, S. L. (2014). Service-Dominant Logic: Premises, Perspectives, Possibilities. Cambridge: Cambridge University Press.

Maslen, A. (2015). Persuasive Copywriting: Using Psychology to Influence, Engage and Sell. London: Kogan Page.

McCole, P. (2004). Refocusing Marketing to Reflect Practice: The Changing Role of Marketing for Business. Marketing Intelligence \& Planning, 22(5), 531-539.

McDonald, M. (2017). Malcolm McDonald on Marketing Planning: Understanding Marketing Plans and Strategy. London: Kogan Page.

McKenna, R. (1995). Real Time Marketing. Harvard Business Review, July-August, 87-98. McKenna, R. (1997). Real Time: Preparing for the Age of the Never Satisfied Customer. Boston: Harvard Business School Press.

Miles, C. (2010). Interactive Marketing: Revolution or Rhetoric? London: Routledge.

Miles, C. (2014). The Rhetoric of Managed Contagion: Metaphor and Agency in the

Discourse of Viral Marketing. Marketing Theory, 14(1), 3-18.

Miles, C. (2016). Control and the Rhetoric of Interactivity in Contemporary Advertising Theory and Practice. In J. Hamilton, R. Bodle, and E. Korin (Eds.), Explorations in Critical Studies of Advertising. London: Routledge, 110-123.

Miles, C. (2017). The Rhetoric of Marketing Co-Creation. In G. Siegert and B. von Rimscha (Eds.), Commercial Communication in the Digital Age-Information or Disinformation? Berlin: De Gruyter.

Muñiz Jr, A. , and Schau, H. (2005). Religiosity in the Abandoned Apple Newton Brand Community. Journal of Consumer Research, 31(4), 737-747.

Nath, P. , and Mahajan, V. (2008). Chief Marketing Officers: A Study of Their Presence in Firms' Top Management Teams. Journal of Marketing, 72(January), 65-81.

Nyilasy, G. , and Reid, L. (2007). The Academician-Practitioner Gap in Advertising. International Journal of Advertising, 26, 425-445.

Oliver, B. , Rust, R. , and Varki, S. (1998). Real-Time Marketing. Marketing Management, 7(4), 29-37.

O'Malley, L. , Patterson, M. , and Kelly-Holmes, H. (2008). Death of a Metaphor: Reviewing the 'Marketing as Relationships' Frame. Marketing Theory, 8(2), 167-187.

Park, H.-S. , Auh, S. , Maher, A. , and Singhapakdi, A. (2012). Marketing's Accountability and Internal Legitimacy: Implications for Firm Performance. Journal of Business Research, 65(11), 1576-1582.

Pearce, W. , and Pearce, K. (2004). Taking a Communication Perspective on Dialogue. In R. Anderson, L. Baxter , and K. Cissna (Eds.), Dialogue: Theorizing Difference in

Communication Studies. Thousand Oaks, CA: Sage, 39-56.

Porter, M. (1979). How Competitive Forces Shape Strategy. Harvard Business Review, 57(2), 137-146.

Prahalad, C. , and Ramaswamy, V. (2004). The Future of Competition: Co-Creating Unique Value With Consumers. Boston: Harvard Business School Press.

Reddy, M. (1979). The Conduit Metaphor: A Case of Frame Conflict in Our Language About Language. In A. Ortony (Ed.), Metaphor and Thought. Cambridge: Cambridge University Press, 284-324.

Reibstein, D. , Day, G. , and Wind, J. (2009). Is Marketing Academia Losing Its Way? Journal of Marketing, 73(July), 1-3.

Ries, A. , and Trout, J. (2001). Positioning: The Battle for Your Mind. London: McGraw-Hill. 
Shaw, M. (2015). Copywriting: Successful Writing for Design, Advertising, and Marketing. London: Laurence King.

Sullivan, L. (2008). Hey Whipple, Squeeze This: A Guide to Creating Great Advertising. Hoboken, NJ: John Wiley \& Sons.

Tell, H. (2011). Plato's Counterfeit Sophists. Washington, DC: Center for Hellenic Studies. Varey, R. J. (2000). A Critical Review of Conceptions of Communication Evident in Contemporary Business and Management Literature. Journal of Communication Management, 4(4), 328-340.

Varey, R. J. (2008). Marketing as an Interaction System. Australasian Marketing Journal, 27(1), 79-94.

Vargo, S. L. , and Lusch, R. F. (2004). Evolving to a New Dominant Logic for Marketing. Journal of Marketing, 68(1), 1-17.

Vargo, S. L. , and Lusch, R. F. (2015). Institutions and Axioms: An Extension and Update of Service-Dominant Logic. Journal of the Academy of Marketing Science, 1-19.

Verhoef, P. C. , and Leeflang, P. S. H. (2009). Understanding the Marketing Department's Influence Within the Firm. Journal of Marketing, 73(2), 14-37.

Williams, R. (1980). Problems in Materialism and Culture. London: Verso.

Williamson, J. (2002). Decoding Advertisements: Ideology and Meaning in Advertising. London: Marion Boyars. 